\title{
PENGEMBANGAN KERAJINAN ANYAMAN PALITAN, DI DUSUN NGLENGKONG, DESA GIRIPURWO, KECAMATAN GIRIMULYO, KABUPATEN KULON PROGO
}

\author{
Juhari $^{1}$, Rossi Maunofa Widayat ${ }^{2}$, Mujiyana ${ }^{1)}$ \\ 1)Program Studi Ilmu Pemerintahan, FISIPOL, Universitas Muhammadiyah Yogyakarta, Yogyakarta, Jawa Tengah, \\ Indonesia \\ 2)Program studi IImu Pemerintahan, FISIPOL, Universitas Muhammadiyah Mataram, Mataram, NTB, Indonesia \\ Corresponding author : Juhari \\ E-mail : Juharisamsitoaji@gmail.com
}

\section{Diterima 26 Agustus 2020, Direvisi 05 Oktober 2020, Diterima 06 Oktober 2020}

\begin{abstract}
ABSTRAK
Permasalahan dari mitra pengabdi kami adalah usaha mengembangkan skala ekonomi dengan industri kerajinan anyaman palitan di Dusun Nglengkong, Desa Giripurwo, Kabupaten Kulonprogo, yang masih mengalami berbagai kendala. Diantaranya, banyak penduduk Dusun Nglengkong yang bekerja di Industri kerajianan namun belum memiliki organisasi (lembaga) bagi buruh kerajinan. Kemudian alat dan cara pembuatannya masih kerajinan manual dan tradisional. Pemasaran masih melalui pengumpul/koordinator, sehingga daya tawar rendah. Dari permasalahan mitra tersebut UMY melalui program pengabdian kepada masyarakat, disinergikan melalui Kuliah Kerja Nyata (KKN) yang bertujuan untuk memotivasi masyarakat pengrajin serta meningkatkan kualitas dan standar produk dengan menambah jenis produk kerajiannnya. Metode yang dilakukan melalui sosialisasi dan pelatihan yang melibatkan sepuluh orang mahasiswa KKN dan tiga orang tim pengabdi. Hasil kegiatan meliputi sosialisasi dan pelatihan yang diikuti sekitar 22 pengarajian anyaman mulai terinisiasi untuk membentuk wadah organisasi yang struktur organisasinya merupakan bagian para pengrajin yang ada di Dusun Ngelengkong, menambah wawasan para pengrajin anyaman Dusun Nglengkong yang awalnya tidak semuanya mengetahui cara pembuatan anyaman palitan begitu pula dengan anyaman yang menggunakan senar, serta kegiatan ini membantu produsen memasarkan produk mereka melalui sosial media yang dapat diakses secara online.
\end{abstract}

Kata Kunci : industri kerajinan; penguatan; sosialisasi; pemasaran; produk unggulan desa

\begin{abstract}
The issue for our service partners is the effort to build economies of scale in Nglengkong Hamlet, Giripurwo Village, Kulonprogo Regency with the Palitan woven handicraft industry, which is still experiencing various obstacles. Among them, many Nglengkong Hamlet residents work in the handicraft industry but do not yet have a handicraft workers' association (institution). The methods and production processes are still manual and traditional crafts. Marketing is still through collectors / coordinators, so there is little bargaining power. UMY, through community service programs, is synergized from the partner issues through the Community Service Program, which seeks to inspire the community of craftsmen and increase the quality and standard of products by increasing the types of craft products. The strategy used consists of socialization and instruction involving ten students from the Community Service Program and three service teams. The results of the activity included socialization and training which was attended by around 22 weaving craftsmen who began to be initiated to form an organizational forum whose organizational structure is part of the craftsmen in Ngelengkong Hamlet, adding to the insight of the Nglengkong Hamlet weaving craftsmen who initially did not all know how to make palitan weaving as well as woven using strings, as well as this activity to help producers market their products through social media that can be accessed online.
\end{abstract}

Keywords : craft industry; strengthening; socialization; marketing; superior product of the village

\section{PENDAHULUAN}

Salah satu cara dalam pembangunan ekonomi ini dengan mengoptimalkan produk unggulan atau komoditas unggulan. Produk unggulan ini akan memberikan manfaat dalam pengoptimalan sumber daya yang ada dan mampu memberikan suatu pengetahuan tentang suatu bahan yang memiliki nilai ekonomis lebih (Lesmana, 2014). Selain itu, 
dengan adanya produk unggulan mampu menimbulkan potensi peningkatan ekonomi masyarakat suatu wilayah tersebut

(Jufriyanto, 2019).

Permasalahan tentang perekonomian sangatlah penting. Hal ini menandakan bahwa dengan meningkatnya perekonomian suatu daerah maka tingkat taraf kesejahteraan juga meningkat. Hal ini juga berhubungan dengan pembangunan ekonomi. Menurut Chuzaimah dan Mabruroh (2008) menyatakan bahwa pembangunan ekonomi adalah suatu proses dimana suatu masyarakat menciptakan suatu lingkungan yang mempengaruhi hasil-hasil indikator ekonomi seperti kenaikan kesempatan kerja, peningkatan pendapatan dan perbaikan taraf hidup. Lingkungan yang dimaksud sebagai sumber daya perencanaan meliputi tentang lingkungan fisik, peraturan dan perilaku. Dalam pembangunan ekonomi terdapat kesenjangan ekonomi antar daerah yang berakibat pada rendahnya tingkat pendapatan masyarakat dan bahkan kemiskinan, adalah masalah yang belum terselesaikan. Dalam hal ini pembangunan masih berorientasi sektoral dan kurang memperhatikan karakteristik dan kondisi dari sumber daya suatu wilayah, sedangkan sumber-sumber daya pembangunan semakin terbatas (Fachrizal, 2016; Yomalinda, 2014)

Menurut Pantow et.al (2015) menyatakan bahwa Pertumbuhan ekonomi mempunyai peranan yang sangat penting, sehingga perlu adanya perencanaan yang matang dalam meningkatkan kinerja dan orientasi pembangunan. Selain itu, menjamin keterkaitan dan konsistensi antara perencanaan, penganggaran, pelaksanaan dan pengawasan sehingga dapat mengoptimalkan partisipasi masyarakat dalam perencanaan pembangunan untuk tercapainya pembangunan secara efisien dan efektif (Anam \& Susilo, 2018)

Dalam menghadapi permasalahan tersebut maka diperlukan pengoptimalan potensi wilayah baik dari sumber daya alam, sumber daya manusia serta sumber dana lainnya untuk pembangunan ekonomi daerahnya. Salah satu cara dalam pembangunan ekonomi ini dengan mengoptimalkan produk unggulan atau komoditas unggulan. Menurut Hidayah (2010) menyatakan bahwa komoditas unggulan adalah komoditas andalan yang memiliki posisi strategis untuk dikembangkan di suatu wilayah. Posisi strategis ini didasarkan pada pertimbangan teknis (kondisi tanah dan iklim), sosial ekonomi dan kelembagaan (Raharja, M. A., Putra, I. M. W. A., 2017; Yulika, 2017).
Salah satu potensi yang ada di Dusun Nglengkong, Giripurwo, Girimulyo, Kulon Progo adalah anyaman palitan. Anyaman palitan adalah kerajinan tangan yang memanfaatkan tanaman pandan liar. Anyaman ini dapat berbentuk berupa keranjang, tikar, tas dan sebagainya. Masyarakat yang menggeluti kerajinan ini belum dapat berinovasi lebih, masyarakat belum banyak mencoba model baru dalam proses produksinya sehingga variasi motif dan model kerajinan masih monoton. Pengrajin anyaman palitan di Dusun Nglengkong ini senantiasa berupaya lebih untuk menambah penghasilan (Kurnia, 2018).

Pengrajin di Dusun Nglengkong saat ini hanya menjadi buruh industri. Sistem yang berlaku adalah pengrajin menerima bahan baku dari pengusaha kerajinan untuk dijadikan bentuk yang sesuai pesanan dan akan menyerahkan hasilnya pada saat waktu yang ditentukan. Bahan utama yang digunakan berupa pandan, gedebong pisang dan tali raffia yang dililit menggunakan mesin. Mesin ini hanya dimiliki oleh pengusaha sedangkan untuk menganyam kerajinan, pengrajin hanya menggunakan tangan untuk membuat anyaman palitannya.

Kegiatan pemasaran yang dilakukan pengrajin yaitu pengumpulan produk ke pengepul. Hal ini tidak efektif bagi pengrajin karena harga yang dibayarkan sangat rendah tidak sebanding dengan harga yang dijual kepada konsumen. Standar harga jual pengrajin yang berbeda-beda menjadikan persaingan antar pengrajin. Persaingan ini yang menyebabakan beberapa pengrajin tidak lagi menggeluti kerajinan ini

Pengrajin di Dusun Nglengkong juga belum mempunyai lembaga/organisasi. Padahal dengan adanya lembaga ini dapat membantu pengrajin dalam pembuatan perencaanan bisnis, memudahkan dalam mencapai target hingga menimbulkan kebersamaan dan semangat kerja. Struktur lembaga/organisasi ini dapat dibentuk berdasarkan hasil musyawarah dan kesepakatan bersama.

Dari hasil survey tim pengbdi dan anggota KKN yang berada di lokasi Dusun Klengkong, Desa Giripurwo, maka pengabdi memandang perlu untuk memberikan solusi berupa sosialisasi mengenai penguatan organisasi (lembaga) bagi buruh sehingga lebih kuat dalam manajemen usahanya, mengadakan berbagai pelatihan yang bertujuan untuk memotivasi masyarakat pengrajin serta meningkatkan kualitas dan standar produk dengan menambah jenis produk kerajiannnya. 


\section{METODE}

Metode yang digunakan dalam kegiatan pengabdian masyarakat dalam menjawab permasalahan yang terjadi pada mitra pengabdi yakni bersama anggota mahasiswa KKN yang berjumlah sepuluh orang. Program pengabdian ini dilaksanakan selama lima bulan (Februari-Juli) 2020. Beberapa strategi /teknis keberhasilan dalam menjalankan program kerja di Dusun Nglengkong, yaitu : Pertama, Sosialisasi pemberian edukasi yang berupa kegiatan sosialisasi dilaksanakan dengan mendatangkan pemateri yang berkompeten dibidangnya. Kegiatan ini bertujuan menyampaikan pengetahuan baru atau tambahan sembari menampilkan gambar dalam bentuk presentasi yang menarik. Kedua, Pelatihan dilaksanakan untuk kegiatan program pokok (Pelatihan Anyaman Palitan) dimana dengan praktik langsung untuk mencapai tujuan yang bersifat psikomotorik. Ketiga, Pendampingan motivasi kewirausahaan bertujuan untuk meningkatkan minat masyarakat dalam membangun dan mengembangkan usaha mereka. Keempat, Pembuatan marketplace via online, bertujuan untuk memudahkan pengrajin dalam memasarkan produknya dengan menampilkan barang hasil produksi melalui media online.

Sebelum melakukan penelitian tim pengabdian bersama anggota mahasiswa KKN yang berjumlah 10 orang yang ikut mempersiapkan pelaksanaan kegiatan $\mathrm{KKN}$ PPM dengan kegiatan meliputi pertama, Penyusunan jadwal agenda, persiapan ini dilakukan untuk meyusun jadwal-jadwal kegiatan bersama anggota KKN, agar jadwal agenda yang sudah dipersiapkan sesuai dengan jadwal program kegiatan yang sudah disusun oleh anggota KKN. Sehingga kegiatan KKN-PPM juga masuk dalam kegiatan program pada mahasiwa KKN selama proses kegiatan KKN.

Kedua, Modul materi pelatihan, persiapan ini dilakukan oleh tim pengabdian masyarakat dengan nantinya sesuai jadwal yang telah ditentukan akan mengundang nara sumber-nara sumber terkait program kegiatan yang akan disampaikan dalam bentuk sosialisasi, pelatihan yang pesertanya dari kelompok-kelompok masyarakat pengrajin anyaman di Dusun Klengkong. Nantinya para peserta akan dibagikan modul/materi dari setiap kegiatan yang diikuti.

Ketiga, Persiapan sarana dan prasarana, persiapan ini dilakukan antara tim pengabdian masyarakat dengan anggota KKN yang berjumlah 10 orang untuk berkoordianasi dengan perangkat desa terkait ketersediaan sarana dan prasarana selama proses kegiatan. (4) Kordinasi lapangan, persiapan ini dilakukakan dengan melibatkan anggota KKN serta mitra pelaksanaan program pengabdian masyarakat yaitu dari Kepala Dusun Ngelongkong dan juga dibantu oleh beberapa anggota karang taruna yang berjumlah tiga orang yang nantinya memiliki peran dalam setiap kegiatan sehingga diharapkan semua proses kegiatan berjalan dengan lancar. Setiap kegiatan anggota KKN di bagi menjadi dua tim yang memiliki tugas dan tanggungjawab yang berbedabeda di setiap kegiatan yang dilaksanakan

Kelima, Sosialisasi dengan mengumpulkan semua stakholders yang terlibat, persiapan ini dilakukan tim pengabdian dengan mengundang stakholders diantaranya tokoh tokoh pemuda, tokoh masyarakat, aparatur desa, dan kelompok masyarakat pengrajin anyaman dengan maksud serta tujuan pemberitahuan terkait kegiatan pengabdian masyarakat ini serta menerima masukan dari berbagai pihak mengenai program-program yang akan dilaksanakan.

Tahap evaluasi dari kegiatan ini nantinya akan dilakukan oleh LP3M UMY berupa post test dalam bentuk kuisioner melalui mitra pengabdian masyarakat. Kuisioner ini dilakukan untuk mengetahui capaian yang sudah atau yang belum dilakukan dari setiap proses kegiatan oleh tim pengabdi UMY.

\section{HASIL DAN PEMBAHASAN}

Bila dilihat dari aspek geografisnya

Dusun Nglengkong merupakan salah satu Dusun yang terletak di Desa Giripurwo, Kecamatan Girimulyo, Kabupaten Kulon Progo Daerah Istimewa Yogyakarta. Dusun Nglengkong pada bagian utara berbatasan dengan Dusun Pendoworejo, pada bagian barat berbatasan dengan Dusun Kebonromo, pada bagian selatan berbatasan dengan Karanganyar, pada bagian timur berbatasan dengan Grigak. Dusun Nglengkong sendiri terdiri dari 6 (enam) RT dan 4 (empat) RW. Dusun Nglengkong mempunyai luas wilayah $86,3575 \mathrm{Ha}$. Luas wilayah ini digunakan sebagai lahan pertanian dan lahan pemukiman warga. Pertanahan yang berada di Dusun Nglengkong di miliki oleh Dusun, perorangan dan Pemerintah. Kantor Kecamatan Girimulyo tepat berada di Dusun Nglengkong, untuk jarak dengan pusat Kabupaten Kulon Progo 9,9 km dan berjarak $21 \mathrm{~km}$ dari provinsi kota Daerah Istimewa Yogyakarta. Lebih dari $80 \%$ penduduk Dusun Nglengkong sendiri bermata pencaharian sebagai petani dengan luas kepemilikan lahan di Dusun Nglengkong sendiri mencapai $15 \mathrm{Ha}$ dengan kondisi lahan 
pertanian mayoritas petani sawah dan ladang, dengan kondisi lahan pertanian yang baik dan topografi lahan yaitu dataran tinggi.

Sedangkan dari aspek demografis dan ketenagakerjaan Dilihat dari aspek demografis dan ketenagakerjaan, Dusun Nglengkong memiliki penduduk berjumlah 180 Kepala Keluarga. Berdasarkan kelompok usia/umur, Dusun Nglengkong memiliki 307 jiwa yang berkelamin laki-laki dan 357 jiwa. Berdasarkan kelompok agama sebanyak 664 jiwa merupakan penduduk beragama Islam. Untuk jumlah penduduk menurut tingkat pendidikannya, sebanyak 7 jiwa tidak menempuh pendidikan sekolah, 27 jiwa telah menempuh pendidikan Sekolah Dasar, 38 jiwa menempuh pendidikan SMP, 57 jiwa menempuh pendidikan SMA/ SLTA, 3 jiwa menempuh pendidikan Perguruan tinggi. Berdasarkan jumlah penduduk menurut mata pencaharian, ada 6 jiwa bekerja sebagai PNS, 71 jiwa bekerja sebagai Pegawai Swasta, 111 jiwa bekerja sebagai petani, dan 10 jiwa bekerja sebagai lain - lain.

Hal ini menunjukkan bahwa mayoritas masyarakat Dusun Ngelengkong telah memiliki mata pencaharian. Sehingga keberadaan kerajinan anyaman palitan merupakan sumber penghasilan tambahan dan menjadi kegiatan sampingan bagi sebagian masyarakat di Dusun Nglengkong, namun keberadaan kerajinan ini bisa menjadi pusat kerajianan anyaman jika masyarakatnya mau mengelolanya dengan manajemen yang lebih professional dikarenakan berpotensi memiliki nilai ekonomis. Untuk jumlah pengrajin anyaman palitan di Dusun Nglengkong saat ini sebanyak 22 orang pengrajin dan sebagian besar didominasi oleh perempuan berumur sekitar 45 tahun. Pengrajin anyaman palitan di Dusun ini sudah berkecimpung dalam pembuatan produk anyaman ini kurang lebih 3-5 tahunan.

Peran masyarakat dalam mengelola kerajinan anyaman palitan disini hanyalah sebagai tenaga kerja bukan sebagai wirausaha yang menjual produk yang mereka olah dari bahan mentah ke bahan yang setengah jadi dengan harga yang mereka tentukan. Masyarakat yang berperan dalam mengolah kerajinan tersebut mendapatkan bahan-bahan untuk memproduksi anyaman tersebut dari pengepul dan mereka hanya diberikan biaya pembuatan sekitar 7000 per produk.

Permasalahan mengenai pengembangan kerajinan anyaman palitan di Dusun Nglengkong yaitu belum terbentuknya wadah bagi kelompok pengrajin agar mampu berdiri sendiri dan tidak bergantung dengan pihak lain. Wadah atau struktur organisasi merupakan suatu susunan dari banyak komponen atau unit kerja pada suatu organisasi. Dalam struktur organisasi pada suatu kelompok berisikan tentang pembagian tugas dan tanggung jawab pada setiap anggotanya. Dengan adanya struktur organisasi dapat dengan mudah mengkoordinir setiap anggotanya dalam pelaksanaan kegiatan untuk dapat mengembangkan kerajinan dan dapat menemukan titik temu dalam menyelesaikan suatu masalah.

Mengingat pentingnya suatu wadah atau struktur organisasi tersebut, maka pengabdi berkerjasama dengan Dinas Perindustrian dan Perdagangan (DISPERINDAG) Kabupaten Kulon Progo, Daerah Istimewa Yogyakarta dalam mengadakan program kerja yaitu "Sosialisasi Pengembangan Kerajinan Anyaman Palitan" pada tanggal 25 Februari 2020 yang dilakukan di Pendhapa Sastro Suwarnan (Balai Padukuhan) dusun Nglengkong.

Dalam kegiatan sosialisasi anyaman palitan yang kami selenggarakan dengan pihak dinas perindustrian dan perdagangan kabupaten Kulon Progo yang didampingi oleh ibu Tri Driyanti selaku perwakilan dari Dinas Perindustrian. Beliau memberikan pemahaman mengenai kebijakan industri produk kerajinan kepada para pengrajin serta memberikan pemahaman mengenai pentingnya kemandirian usaha dalam kegiatan untuk membentuk jiwa wirausaha dengan dibentuknya suatu wadah dalam kegiatan pengrajin anyaman palitan.

Dari kegiatan ini ditemukan bahwa pengumpulan informasi dan biodata pengrajin menjadi faktor pendukung dari kegiatan ini. Biodata-biodata yang dikumpulkan dapat memudahkan jika ada pembentukan organisasi. Namun ada beberapa pengrajin yang belum menyerahkan biodata dirinya. Dari informasi yang didapat, masalah yang dialami pengrajin dapat diketahui, sehingga masalah dapat menjadi evaluasi perbaikan kedepannya. 


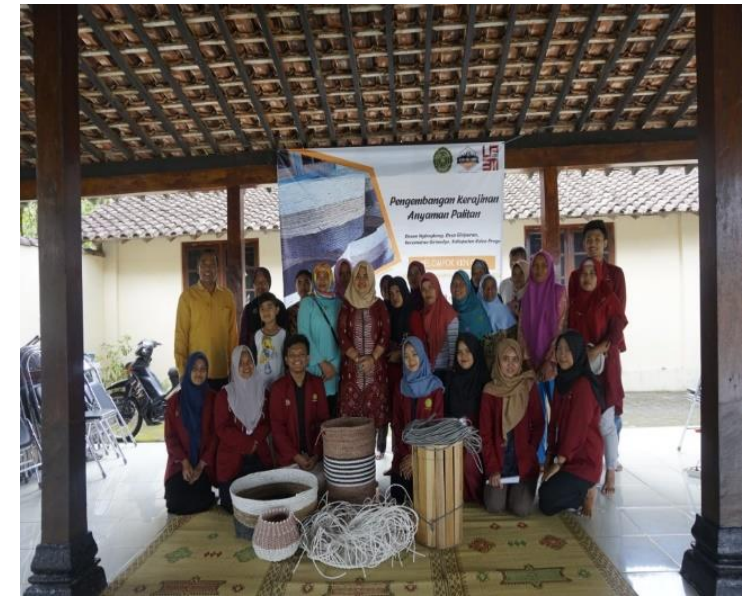

Gambar 1. Kegiatan Sosialisasi Anyaman

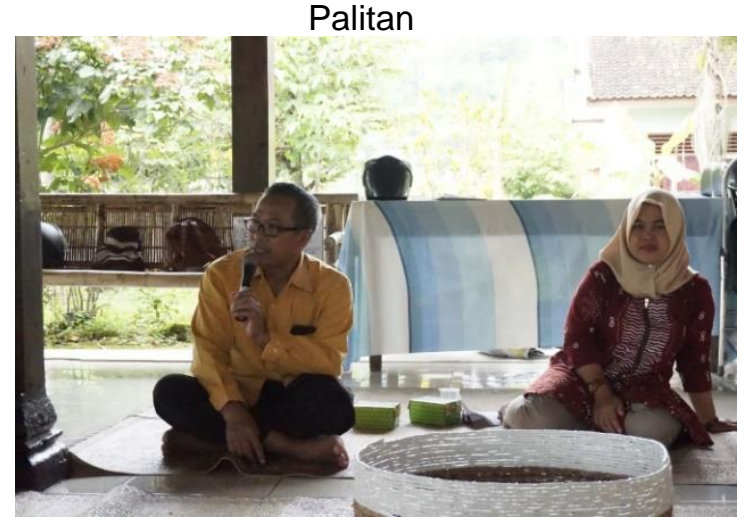

Gambar 2. Kegiatan Sosialisasi Anyaman Palitan

Dari gambar $1 \& 2$ menunjukkan bahwa program ini dilakukan sebagai bentuk kontribusi UMY kepada masyarakat di Dusun Nglengkong. "Dengan sosialisasi ini diharapkan warga pengerajin di Nglengkong dapat berkembang menjadi lebih maju, sehingga Dusun Nglengkong memiliki ciri khas yaitu Anyaman Palitan.

Setelah melaksanakan kegiatan sosialisasi, tim juga melaksanakan kegiatan pelatihan. Pelatihan ini dihadiri oleh para pengrajin anyaman palitan Dusun Nglengkong. Dinas Perindustrian dan Perdagangan Kulon Progo juga menghadiri pelatihan anyaman palitan ini.

Terdapat dua jenis kerajinan anyaman yang ada di Dusun Nglengkong, yaitu kerajinan anyaman palitan dan kerajinan anyaman menggunakan senar. Penggunaan senar atau tidaknya tersebut yang membedakan jenis kerajinannya. Anyaman palitan dikatakan lebih rumit dibandingkan dengan anyaman yang menggunakan senar. Hal ini dikarenakan pola yang dibuat hanya menggunakan bahan pokoknya saja yaitu tali rafia. Anyaman palitan yang biasa dibuat yaitu karpet berbentuk lingkaran dengan diameter yang beragam sesuai dengan pesanan. Adapula anyaman palitan yang bentuk guci dan keranjang. Kerajinan anyaman yang menggunakan senar biasanya berbentuk tas laundry dengan tiga ukuran yang berbeda.

Pengrajin anyaman yang ada di Dusun Nglengkong tidak semuanya mengetahui cara pembuatan anyaman palitan begitu pula dengan anyaman yang menggunakan senar. Seorang pengrajin hanya membuat satu jenis kerajinan anyaman sehingga tidak menguasai semua jenis kerajinan yang ada. Oleh karena itu pelatihan ini menggunakan "metode tutor sebaya" dengan tujuan antar pengrajin dapat mengajari cara masing-masing jenis anyaman.

Produk-produk anyaman yang dibuat oleh para pengrajin sebagian besar memiliki model dan warna yang sama sehingga tidak terdapat variasi pada produk anyaman palitan. Pada pelatihan ini, pengrajin diberi beberapa contoh gambar modifikasi anyaman palitan dari social media maupun dari sumber internet lainnya. Contoh-contoh gambar modifikasi yang diberikan memiliki warna dan fitur tambahan yang lebih menarik tetapi bentuk yang ditampilkan sama seperti bentuk yang dibuat oleh para pengrajin

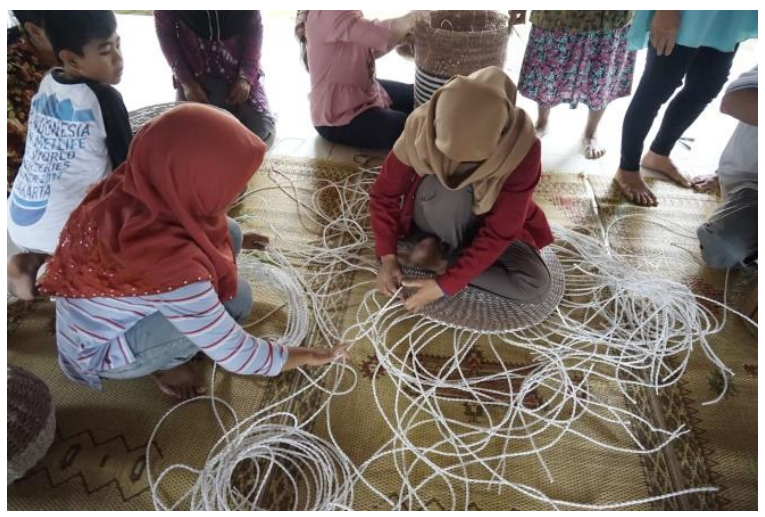

Gambar 3. Pelatihan Anyaman Palitan

Dari gambar 3 menunjukkan bahwa Dengan adanya pelatihan tutor sebaya, pengrajin yang sebelumnya belum mengetahui cara pembuatan anyaman palitan dapat membuat anyaman palitan sendiri begitu pula dengan anyaman menggunakan senar. Pada saat pelatihan, pengrajin yang biasa membuat anyaman palitan mengajarkan cara membuat anyaman palitan dengan perlahan-lahan. Pengrajin anyaman menggunakan senar juga menunjukkan cara membuat anyaman menggunakan senar dengan seksama agar mudah dimengerti oleh pengrajin lainnya.

Kegiatan trakhir dari program pengabdian ini yakni pendampingan motivasi kewirausahaan. Kegiatan ini dilaksanakan bertempat di Pendhopo Sastro Suwarnan (Balai Padukuhan). Alien Akmalia, SE., M.Sc, Pengajar di Prodi Manajemen FEB UMY 
(Kewirausahaan, Pengelolaan Usaha, Manaajemen Bisnis, Manajemen Keuangan, Manajemen Investasi, Komputer Bisnis, Penganggaran Perusahaan, Matematika Bisnis), hadir dalam kegiatan ini sebagai pemateri acara yang berjudul Motivasi Kewirausahaan.

Motivasi kewirausahaan sangat dibutuhkan oleh warga Dusun Nglengkong untuk meningkatkan minat masyarakat dalam membangun dan mengembangkan usaha mereka. Dalam kegiatan ini, pemateri menyampaikan konsep wirausaha, perbedaan antara pedagang dan pengusaha, contoh pengusaha sukses, dan motivasi berwirausaha dari segi keagamaan.

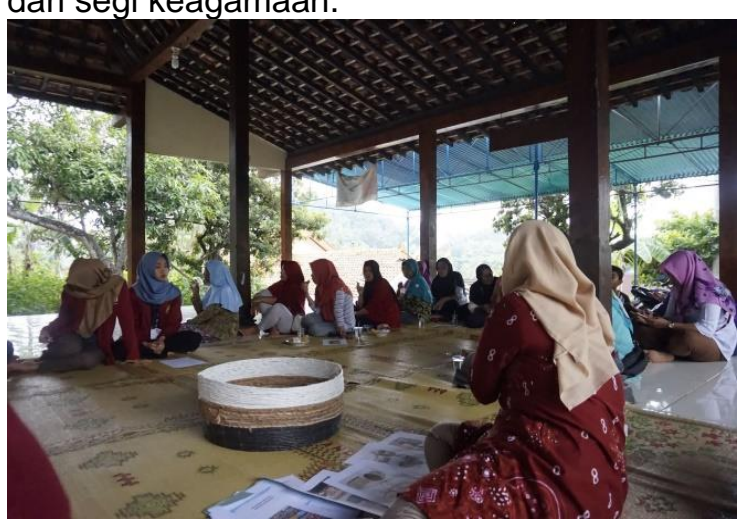

Gambar 4.Pendampingan Motivasi Kewirausahaan

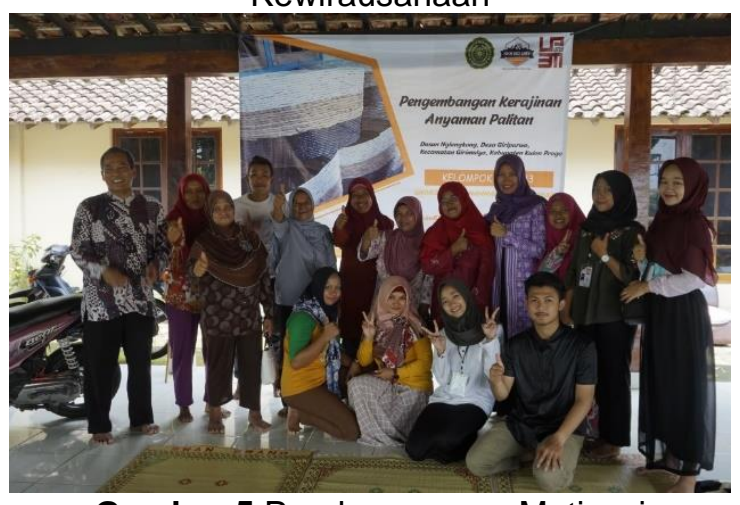

Gambar 5.Pendampungan Motivasi Kewirausahaan

Keadaan ekonomi masyarakat Dusun Nglengkong masih terbilang kurang, hal itu dikarenakan mayoritas masyarakat bekerja sebagai petani yang mengolah lahan sawah orang lain atau bukan milik pribadi sehingga mereka tidak mendapat pemasukan yang cukup dari pekerjaan tersebut.

Kegiatan ini diharapkan dapat menumbuhkan minat masyarakat Dusun Nglengkong untuk memulai dan mengembangkan usaha mereka sendiri. Dengan diadakannya sosialisasi ini juga diharapkan masyarakat memiliki penghasilan yang lebih dan bersifat mandiri. Dengan begitu, keadaan ekonomi di Dusun Nglengkong bisa menjadi lebih baik.

Keinginan masyarakat Dusun Nglengkong untuk meningkatkan keadaan ekonomi mereka membuat masyarakat lebih antusias dalam menghadiri kegiatan ini. Beberapa remaja yang hadir juga menjadi bukti bahwa kegiatan ini sangat diminati masyarakat Dusun Nglengkong yang berusia muda.

Faktor yang menjadi penghambat masyarakat dalam berkembang adalah keterbatasan mereka dalam memiliki dana sebagai modal usaha. Meskipun keinginan mereka untuk berkembang sudah ada, akan tetapi mereka cenderung takut untuk memulai usaha karena keterbatasan modal tadi sehingga mereka terjebak pada zona nyaman mereka sebagai buruh

Penggunaan teknologi sangat membantu manusia dalam berbagai aspek termasuk dalam hal pemasaran. Pada zaman modern seperti saat ini, kegiatan jual beli tidak selalu harus dilakukan secara langsung. Pemasaran dapat dilakukan dengan 2 metode yaitu dengan metode offline dan online.

Kegiatan ini memfasilitasi produsen dalam hal pemasaran dengan pembuatan market place via online. Online yang dimaksud adalah penggunaan sosial media yaitu Instagram. Di Instagram, produsen bisa memasarkan produknya dengan menampilkan barang hasil produksi mereka sekaligus memberikan informasi berupa harga maupun bahan produksi. Dengan Instagram tadi, calon pembeli dan penjual juga dapat berkomunikasi dengan layanan Direct Message

Produsen kadang tidak selalu punya modal tambahan untuk membuka warung atau lapak mereka sendiri. Dengan begitu, mereka harus mencari jalan lain demi menjual produk mereka. Kegiatan ini membantu produsen memasarkan produk mereka melalui sosial media yang dapat diakses secara online. Dengan adanya kegiatan ini diharapkan dapat membuat produsen mampu mengembangkan pemasaran mereka secara nasional dan internasional

Seperti yang sudah disebutkan sebelumnya, sosial media lebih sering diakses oleh anak muda. Sehingga dalam pendampingan kewirausahaan ini diharapkan ada juga kontribusi dari anak muda untuk memasarkan hasil produksi kerajinan anyaman palitan. Pengrajin di Dusun Nglengkong semuanya adalah orang tua, ada juga yang lansia, maka dari itu mereka kurang menguasai teknologi ini sehingga sedikit mengalami kesulitan saat pelaksanaannya. Keinginan masyarakat Dusun Nglengkong untuk meningkatkan keadaan ekonomi mereka 
membuat masyarakat lebih antusias dalam menghadiri kegiatan ini. Beberapa remaja yang hadir juga menjadi bukti bahwa kegiatan ini sangat diminati masyarakat Dusun Nglengkong yang berusia muda.

Faktor yang menjadi penghambat masyarakat dalam berkembang adalah keterbatasan mereka dalam memiliki dana sebagai modal usaha, serta keterbatasan dalam pemasaran. Meskipun keinginan mereka untuk berkembang sudah ada, akan tetapi mereka cenderung takut untuk memulai usaha karena keterbatasan modal tadi sehingga mereka terjebak pada zona nyaman mereka sebagai buruh.

\section{SIMPULAN DAN SARAN Simpulan}

Dalam kegiatan pengabdian ini para pengrajin anyaman mulai terinisiasi untuk membentuk wadah organisasi yang struktur organiasinya merupakan bagian para pengrajin yang ada di Dusun Ngelengkong.

Dengan adanya kegiatan ini masyarakat pengrajin anyaman yang ada di Dusun Nglengkong yang awalnya tidak semuanya mengetahui cara pembuatan anyaman palitan begitu pula dengan anyaman yang menggunakan senar. Karena bisanya seorang pengrajin hanya membuat satu jenis kerajinan anyaman sehingga tidak menguasai semua jenis kerajinan yang ada. Karena itu pelatihan ini menggunakan metode tutor sebaya dengan tujuan antar pengrajin dapat mengajari cara masing-masing jenis anyaman. Kegiatan ini membantu produsen memasarkan produk mereka melalui sosial media yang dapat diakses secara online. Dari kegiatan ini, saat ini para pengrajin bisa melayanai pembeli melalui dengan 2 metode yaitu dengan metode offline dan online (Facebook, instagram, dan whatsap).

\section{Saran}

Diharapakan dari kegiatan pengabdian ini bisa terus untuk dilanjutkan dengan model kegiatan yang berbeda, karena masih banyak masyarakat yang membutuhkan sosialisasi, pelatihan seperti kegiatan yang telah dilaksanakan di Dusun Ngelenkong.

\section{DAFTAR RUJUKAN}

Anam, A. K., \& Susilo, E. (2018). INCREASING PRODUCTIVITY AND BUSINESS MANAGEMENT ON RATTAN WEAVING CRAFTSMEN TH. Jurnal Pengabdian Dan Pemberdayaan Masyarakat, 2(2).

Fachrizal, R. (2016). PENGARUH MODAL DAN TENAGA KERJA TERHADAP PRODUKSI INDUSTRI KERAJINAN
KULIT DI KABUPATEN MERAUKE. Jurnal Agribisnis Perikanan, 9(Oktober), 66-75.

Jufriyanto, M. (2019). Pengembangan Produk Unggulan Sebagai Potensi Peningkatan Ekonomi Masyarakat Desa di Kecamatan Modung Bangkalan. Jurnal Pengabdhi, 5(1).

Kurnia, A. (2018). Peningkatan Jumlah Produksi Kerajinan Anyaman Tas Dengan Alat Pemotong Dan Pengukur Tali Pengepek. Jurnal Pengabdian Dan Pemberdayaan Masyarakat, 2(1), 3742.

Lesmana, A. (2014). PENGARUH MODAL, TENAGA KERJA, DAN LAMA USAHA TERHADAP PRODUKSI KERAJINAN MANIK-MANIK KACA (STUDI KASUS SENTRA INDUSTRI KECIL KERAJINAN MANIK-MANIK KACA DESA PLUMBON GAMBANG KEC. GUDO KAB. JOMBANG). Jurnal IImiah Mahasiswa FEB, 2(2).

Raharja, M. A., Putra, I. M. W. A., \& K. (2017). Peningkatan dan Pengembangan Produksi Usaha Kerajinan Kayu Berbasis Teknologi Tepat Guna di Desa Petulu Kecataman Ubud Gianyar. Jurnal Paradharma, 1(April), 17-22.

Rahayu, D., Nuryadin, M. R., \& Rakhmatullah, A. (2018). THE POTENCY AND THE STRATEGY OF WOVEN CRAFT INDUSTRY DEVELOPMENT IN TAPIN REGENCY. JOURNAL OF ECONOMICS AND DEVELOPMENT STUDIES, 1(1), 27-35.

Sunardi, S. (2019). PKM PENGERINGAN KAYU UNTUK PENINGKATAN PRODUKSI PADA PENGRAJIN KAYU LOKAL DI BANJARBARU, KALIMANTAN SELATAN. Jurnal AlIkhlas, 5, 9-19.

Yomalinda. (2014). KOMODITI UNGGULAN KABUPATEN AGAM Oleh Yolamalinda PENDAHULUAN Pembangunan ekonomi daerah dalam era otonomi daerah menghadapi berbagai tantangan . Di satu pihak, kesenjangan ekonomi antar daerah yang berakibat pada rendahnya tingkat pendapatan masyarakat. Journal of Economic and Economic Education, 3(1), 27-41.

Yulika, R. (2017). PEMBERDAYAAN MASYARAKAT ULAKAN TAPAKIS MELALUI PENGEMBANGAN DESAIN PRODUK ANYAMAN PANDAN Febri. Jurnal Batobah, 2(2). 